\title{
Some Special Features of Kimozero Kimberlites of Onega Flexure (Karelia, Russia)
}

\author{
Z. Dubovikova, Yu. Polekhovsky \\ Saint-Petersburg State University, Saint-Petersburg, Russia
}

\begin{abstract}
Kimberlite formations of Kimozero were discovered in 1992 - 99 by Karelian geologists headed by V.V.Ushkov. This was the first location in Karelia where the presence of diamonds was reliably established (Ushkov, 2001).
\end{abstract}

Kimozero kimberlites is situated within the Povenetz block of Onega flexure situated in the southeastern karelide zone of the Baltic shield, limited by the Svecofennian zone in the south-west and by the Belomorsk zone in the north-east. The Onega flexure is a brachiform synclinorial structure which was formed in the proterozoic era on the granite-gneiss basis of the Archean about 2.6 Ga (Kondakov et al., 1986). Some researchers believe that the basis of the geoblock is a huge granite-gneiss complex of corresponding dimensions which was being formed above a long-living mantle plume (Afanasyev, et al., 2006). The flexure is formed by volcanogenic deposits of the Karelian complex, ranging from SumianSariolian to Vepsian inclusively. The south part of the flexure is overlapped Vend-Paleozoic platform mantle.

The formation of Kimozero kimberlites went through several stages. Three kinds of kimberlites can be distinguished according to the three stages of explosive intrusion. The earliest kimberlites-I have not been yet found in basic bedding. We define them as xenoliths in later explosive formations. The kimberlites-II, as well as the rock containing them, are a part of the brachyanticline structure of the third order which formed as a result of their intrusion into the axial portion of a larger syncline fold made up of metadiabase with thin streaks of shungit-containing siltstone and gabbrodolerites sills of the Zaonezhski Ludicovian complex. Diatrems and dikes of kimberlites-III intersect with the rocks which form the fold (fig.1). Kimozero rocks are among the most ancient of kimberlites; their proterozoic age was determined by the $\mathrm{Sm}-\mathrm{Nd}$ method as $1764 \pm 125 \mathrm{Ma}$ (Mahotkin, 1999).

According to the results of field observations veryfied by petrographic data, we have distinguished bearing gabbrodolerites, diabases and kimberlites proper. Kimberlites-II are represented by tufobreccias, among which we distinguish carbon-containing rocks forming the outer edge, beyond which small fragments of kimberlites and magnetite-containing kimberlites are observed and tuffs. Kimberlites-III are encountered as intruding diatremic formations, among which breccias, tufobreccias and massive tuffs.
These kinds of rock are further subdivided, according to the nature of epigenetic changes, into serpentinous, chloritized and amphibolized varieties.

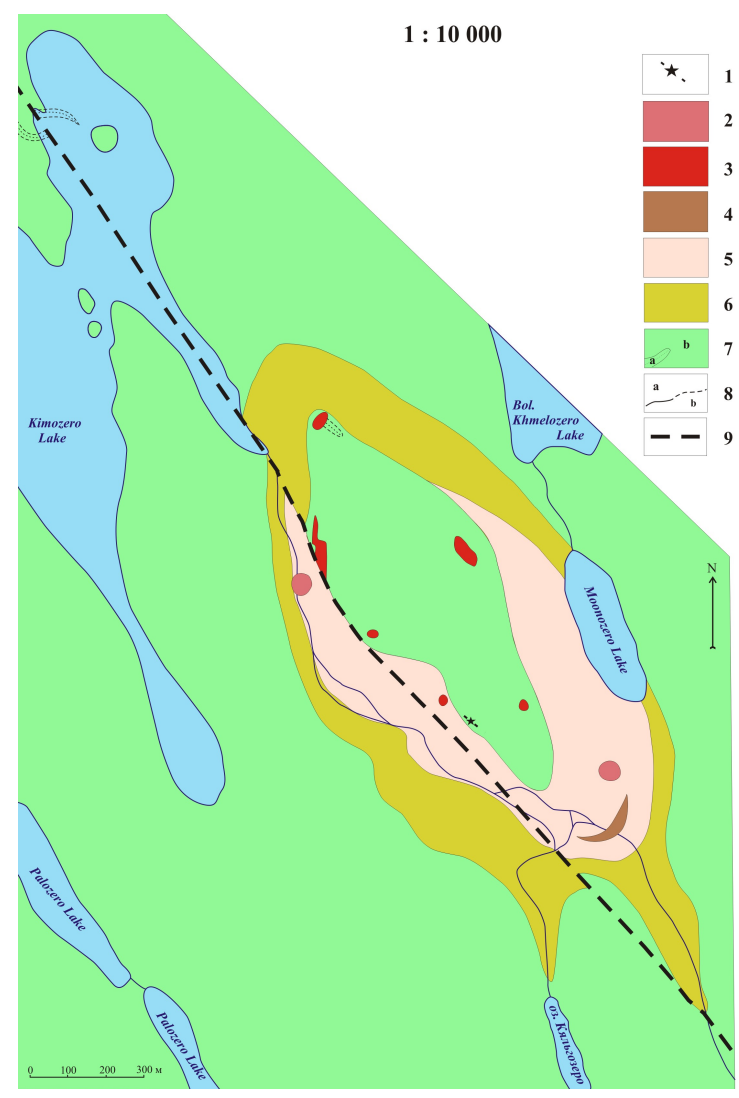

Fig. 1 Geological scheme of a Kimzero territory.

By Z.L.Dubovikova, Yu.S.Polekhovsky, A.Yu.Arefyeva (using data by V.V.Ushkov, V.M.Ustinov et al., 2008). 1 dike of tufobreccias (out of scale); 2 - kimberlite tufobreccias; 3 - kimberlite breccias, tufobreccias and tuffs; 4 - tuffs; 5 - small fragments of tufobreccias and magnetitecontaining tufobreccias; 6 - carbon-containing tufobreccias; 7 - metadiabases (seen as a whole) with tufosiltstone (a) and gabbrodolerite (b) streaks; 8 - geological limits: reliably established (a) and hypothetical (b); 9 - supposed fracture.

The least changed varieties of kimberlites are made up of olivine (up to $70 \%$ ) and phlogopite (up to $50 \%$ ) pseudomorphoses in various proportions, with the presence of xenoliths of mantle and containing kimberlites rock (up to $10 \%$ ), fragments of resurgent origin and isolated autholiths. 
Olivine is completely replaced by serpentine and small magnetite impregnations. The size of phenocrysts varies from 0.1 to $5 \mathrm{~mm}$, grains smaller than $0.1 \mathrm{~mm}$ are encountered less frequently. The grains of the first generation are rockforming in kimberlites-I and xenoliths in the next phase of intrusion. In the first case they have more clearly defined crystallographic outlines; the combination, in one phenocryst, of a smoothed crystal edge and idiomorphic shape of the rest of the crystal is typical (fig. 2 a).Their size can reach $5 \mathrm{~mm}$. Phenocrysts of the second generation are frequently seen in kimberlites-II (fig. 2 a). The outlines of such grains are for the most part blurred by intensive epigenetic processes of serpentinization and subsequent amphibolitization. Their size usually does not exceed $2 \mathrm{~mm}$. The grains of the third generation are encountered in later kimberlites-III (fig. 2 b). They are more often than not idiomorphic, measuring from 0.1 up to $0.7 \mathrm{~mm}$. Besides the morphotypes described above, some varieties of kimberlites (stratified kimberlite tuffs) exhibit skeletal forms of olivine.
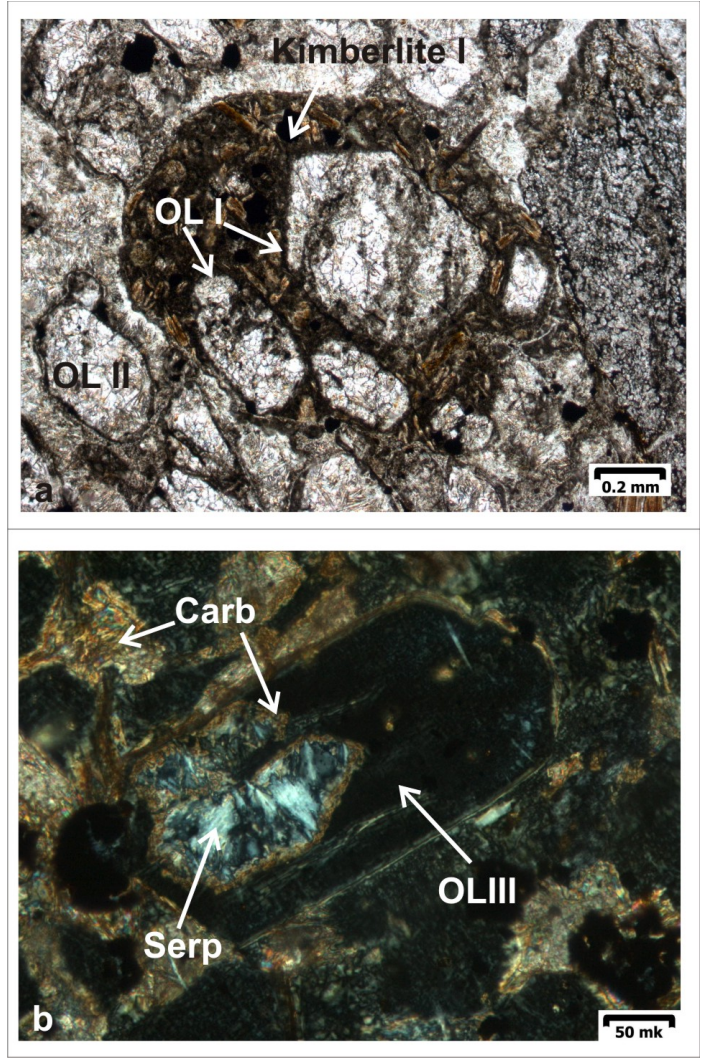

Fig. 2. Microphotograph of thin sections: a olivine I (OL I) pseudomorphoses in xenolith of kimberlite I and olivine II (OL II) pseudomorphoses in matrix of carboncontaining tufobreccia, without analyzer; b - serpentinous (Serp) olivine III (OL III) phenocryst in matrix of carbonaceous tuff, with analyzer.

Phlogopite is mostly replaced in rocks by chlorite and tremolite, less frequently by serpentine, yet sometimes areas and sometimes grains (fig. 3a) which have undergone little change; if pseudomorphoses are not complete, pleochroism is observed ranging from pinky-brown to greenish-yellow colour. Three generations of phlogopite can be distinguished, corresponding to the three stages of kimberlite intrusion. Meaningful differences in morphology between representatives of various generations are absent, and some peculiarities are due to various secondary processes, for instance, pseudomorphoses in carbonaceous rock are worm-shaped (fig. 3b). The size of the crystals varies between $0.2-0.4$ and up to 2-3 $\mathrm{mm}$. Phlogopite has been confirmed radiologically (Dubovikova et al., 2006) and its composition $(n=6)$ corresponds to the calculated formula $\mathrm{K}_{0.36-0.74}\left(\mathrm{Mg}_{2.74-}\right.$ $\left.{ }_{2.92} \mathrm{Fe}_{0.08-0.24}\right)\left(\mathrm{Si}_{2.88-2.96} \mathrm{Al}_{0.96-1.05} \mathrm{Fe}_{0.04-0.14} \mathrm{O}_{10}\right)(\mathrm{OH})_{2}$. It contains up to $27 \%$ of $\mathrm{MgO}$, not more than $7 \%$ of $\Sigma \mathrm{FeO}$, up to $7 \%$ of $\mathrm{K} 2 \mathrm{O}$; the latter number decreases through chloritization. Chlorite phlogopite pseudomorphoses are the ones most frequently observed in sections, though its original form is preserved as isolated oval or roundish (probably melted) crystals.
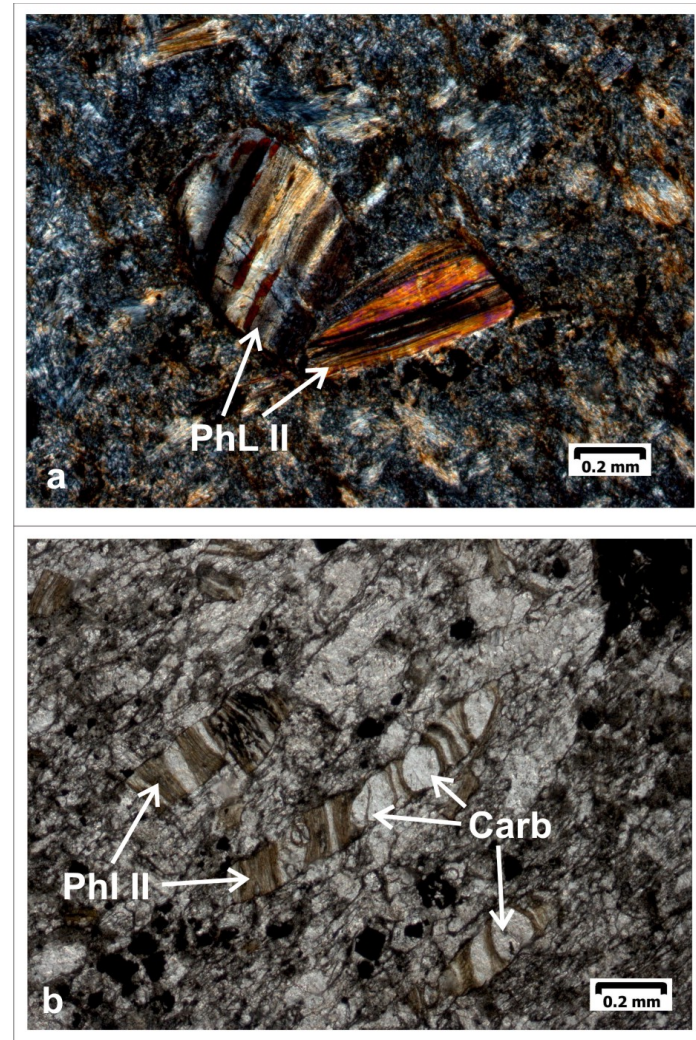

Fig. 3. Microphotograph of thin sections: a phlogopite II, little changed, from the matrix of small fragments of serpentinous tufobreccia, with analyzer; b phlogopite II (PhLII) pseudomorphoses impregnated by carbonate (Carb) from matrix of carbon-containing carbonaceous tufobreccia, without analyzer.

Ore mineralization is represented by minerals accessory of diamonds - chromspinelide and ilmenite, as well as other minerals - titaniferous magnetite, 
magnetite, rutile, titanite, pyrite, chalcopyrite and hematite. The content of ore minerals in some varieties of rock reaches $20 \%$, and in such cases they are concentrated in a subparallel manner, giving the kimberlites a streaked appearance or as sphere-shaped concretions, which is typical of magnetite.

Minerals accessory of diamonds in Kimozero area are chromspinelides and ilmenites. An almost complete absence of pyropes and chromdiopsides among minerals accessory of diamonds is an important feature of the kimberlites. Only rare isolated finds of grains of these minerals have been recorded, which testifies to the impossibility of using pyropes and chromdiopsides as indicators of kimberlites of this kind. The most informative accessory mineral is chromspinelide, of which an important part of analyzed compositions is situated within the areas of diamondiferous kimberlites described by various authors (fig. 4, for example).

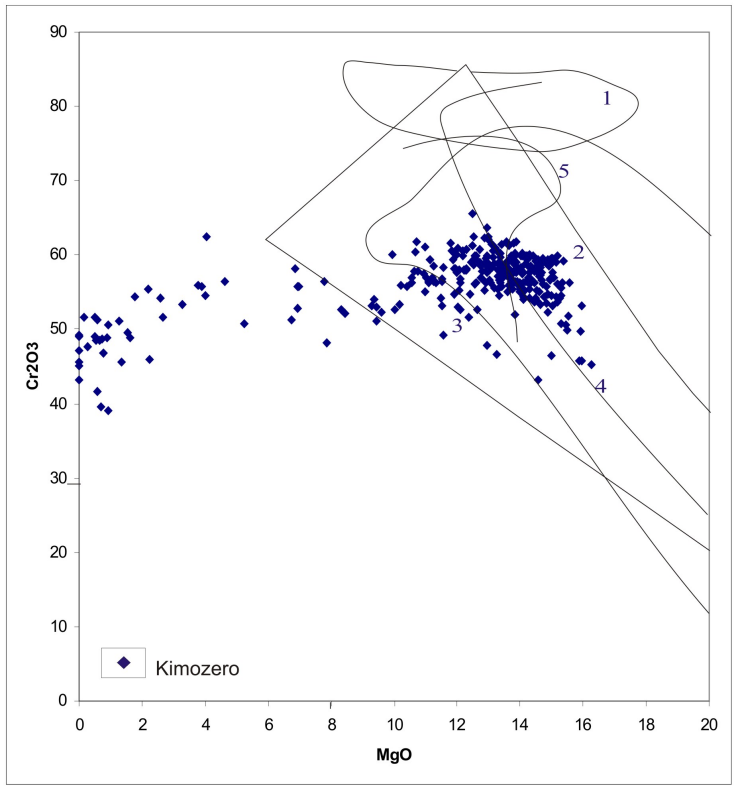

Fig. 4. Specificity of chromspinelides composition $(\mathrm{n}=238)$ on a diagram by Ch.Fipke (Fipke, 1994) by MgO$\mathrm{Cr}_{2} \mathrm{O}_{3}$ axes. The fields according to V.I.Vaganov.: 1 inclusions in diamonds; 2 - generalized field of compositions of the Mir pipe; 3 - Lomonosov deposit (Archangelsk); 4 kimberlites of the Daldyno-Alakitsky region; 5 - lamproites of the Argyle pipe.

The general sequence of secondary changes of kimberlite rocks and their development are as follows: at the earliest stage, serpentization (antigorite and lizardite) takes place, accompanied by formation of ore minerals, then carbonatization and partial silicification of the rocks and, finally, at a late stage, chloritization (clinochlore and shamozite) and amphibolitization (tremolite and actinolite).

The study of the chemical composition of the rocks of Kimozero formation by the means of quantitative spectral analysis and ISP MS methods has confirmed the variety observed petrographically.
A wide variety of petrogenic and accessory elements is typical for the kimberlites of the area, which can be explained by various proportions between the main petrogenic minerals, the specificity of secondary modifications as well as by the possible variations of the primary magmatic composition during different phases of intrusion. The rocks differ not only in the content of "mobile" components ( $\mathrm{Si}, \mathrm{Mg}, \mathrm{Ca}$ and others), but also in the content of "inert" ones (Fe, Ti, $\mathrm{Al}, \mathrm{K}$ and others). According to V.A.Milashev's classification, which was based on the data of Yakutia diamondiferous region and comprises all the kimberlite types found there, representatives of four populations out of seven are present within the limits of the territory in question (Milashev and Tretyakova, 2003). Kimberlites differ also as regards REE (rare earth element) content, and the nature of these differences according to our data is similar to the results obtained by other researchers (Lukyanova et al., 2006).

More than 100 diamond grains have been found (Ushkov, 2001) in samples (weighing from 40 to $3340 \mathrm{~kg}$ ) taken by Ashton Mining Ltd. These findings confirm the diamondiferous nature of kimberlites, yet do not allow assessing its richness because the samples gathered are not representative enough.

Thus the Kimozero kimberlites in Karelia differ from known diamondiferous kimberlites in the following: 1. Pyropes and chromdiopsides are absent from minerals-indicators; 2. Chromspinelides and ilmenites exhibiting a specific composition are prevalent; 3. A high degree of epigenetic rock transformation and a substantial participation of late amphibolitization; 4. A possibly late Karelian genesis.

\section{References}

Afanasyev G.V., Klyuev N.K. , 2006. Structure, formation dynamics and metallogeny of the Onega geoblock (south-east part of the Baltic shield). In: Regional geology and metallogeny. Inst. 28, Saint-Petersburg.

Dubovikova Z.L., Arefyeva A.Yu. Polekhovsky Yu.S., 2006. New findings on mineral composition of Kimozero kimberlites in Karelia, Petrozavodsk.

Fipke, C. E. , 1994. Significance of chromite, ilmenite, G5 Mg-almandine garnet, zircon and tourmaline in heavy mineral detection of diamond bearing lamproite, in Kimberlites, Related Rocks and Mantle Xenoliths, SPRM Spec. Publ. 1A, 1, 366-381.

Kondakov S.N., Petrov Yu.V., Bulavin A.V. et al., 1986. Block and deep structure of Onega flexure. In: Block tectonics and ore prospects of the north-west region of the Russian platform. VSEGEI publishing house, Leningrad, pp. 86-75.

Lukyanova L.I., Lobkova L.P., Alyokhina V.V., 2006. The Specifics of the composition of kimberlite rocks of Kimozero formation in Karelia. In: Diamonds and noble metals of the Timano-Uralsky reg. Syktyvkar.

Mahotkin I.L., 1999.Age and geochemistry of rock samples from the Kemozero occurrence, Karelia, NW Russia. AMI. Report № 52390.

Milashev V.A., Tretyakova Yu.V., 2003. Conditions and factors of kimberlite formation. Saint-Petersburg.

Ushkov V.V., 2001. Kimozero formation of diamondiferous kimberlites in Onega flexure. In: Geology and minerals of Karelia. Inst. 3, Petrozavodsk. 